\title{
Structural alternatives of high embankment dams
}

\author{
Filipp Kotov* \\ Moscow State University of Civil Engineering, Yaroslavskoe shosse, 26, Moscow, 129337, Russia
}

\begin{abstract}
At present the types of seepage-control elements made of nonsoil materials are worked out for construction of ultra-high embankment dams. We made assessment of workability of a number of new structural designs of seepage-control elements for embankment dams such as concrete core, grout curtain, massive face, combined seepage-control elements. The assessment was made by analyzing the results of numerical modeling of more than $200 \mathrm{~m}$ high dam stress-strain state. It was revealed that the most perspective way of constructing high embankment dams is use of combined seepage-control elements. The operative structures are structures consisting of a reinforced concrete face and a vertical structure (like a diaphragm or a curtain), made of clay and cement mix. Use of internal seepage-control elements made of rigid materials in high embankment dams is dangerous.
\end{abstract}

\section{Introduction}

Continuing search for new types of embankment dam structures is due to the fact that use of traditional structural designs either does not provide the required level of dam safety or is not effective from the point of view of cost and construction methodologies. Namely, the issue of using dams of new types is acute at designing high-head projects (with heads exceeding $150 \mathrm{~m}$ ) in the Northern climatic zone of Russia. For example, at designing Kankun project several alternatives of the dam structural design were compared [1,2].

At present at ultra-high heads only two types of embankment dams may be used: a rockearthfill dam with a clay central core and a rockfill dam with a reinforced concrete face. However, in conditions of Siberia the use of these two types of dams is problematic. Complexity in using a rock-earthfill dam with a core is referred to large duration of the cold season, during which placement of clay soil into the core is not allowed. Use of a rockfill dam with a reinforced concrete face is restrained by lack of experience in construction of the dams of the similar type in Russia as well as by the insufficient safety level of dams of this type. Frequently cracks are developed in reinforced concrete faces of ultra-high dams $[3,4]$. Besides, there are concerns that the reinforced concrete face cannot operate in

\footnotetext{
* Corresponding author: KotovFV@mgsu.ru
} 
complicated ice conditions, typical for Siberian rivers, and cannot withstand extreme temperature impacts.

Due to the aforementioned complications the possibility is considered of using embankment dams of other types. One of the possible alternatives is a rockfill dam with an asphalt-concrete diaphragm. This type of the dam was used at Boguchany HPP [5]. However, there is no experience of using such dams at very high heads: the height of the highest dam of this type (Storglomvatn) reaches $125 \mathrm{~m}$. Numerical modeling of a rockfill dam with an asphalt-concrete diaphragm with height about $200 \mathrm{~m} \mathrm{[6]} \mathrm{shows} \mathrm{that} \mathrm{the} \mathrm{stress-}$ strain state (SSS) is unsatisfactory. Under hydrostatic pressure the dam has large settlements which cause development of limit state zones in the upstream shell. As the dam may lose stability it does not have the required safety level.

Impossibility of using traditional structural designs for construction of ultra-high embankment dams conditions the necessity in elaboration and check of new, alternative types of structures. We considered and analyzed a number of such alternatives.

\section{Methods}

We searched for scientific and research information about development of new structural designs of embankment dams [1,2,7-9]. Based on the analysis a list of high embankment dam structural designs was prepared:

- dam with a concrete core,

- dam with a grout curtain,

- dam with a massive non-soil face,

- dam with combination of seepage-control elements: a reinforced concrete face and a clay-cement concrete diaphragm,

- dam with combination of seepage-control elements: a reinforced concrete face and a grout curtain.

All these alternatives have been considered applicable to the conditions of Kankun project in South Yakutia. Maximum overall height of Kankun dam is $235 \mathrm{~m}$. The foundation of the dam is presented by rocks buried under the layer of alluvial deposits.

Assessment of workability of embankment dam structural alternatives was performed with the aid of numerical modeling of their SSS. As rockfill deformation bears non-linear character, SSS was modeled with use of soil non-linear model and with consideration of the dam SSS variation in the process of construction and the reservoir impoundment. The model proposed by Professor L.N. Rasskazov [10] was used as a non-linear model which takes into account all the main features: decrease of deformation at increase of compression, increase of deformation at approaching the limit state.

Studies were carried out for a wide range of rockfill deformation. Calculations were performed for three alternatives of rockfill deformation properties: A, B and C. In alternatives $\mathrm{B}$ and $\mathrm{C}$ the model parameters were adopted 2 times as much and 4 times as much respectively as the parameters in alternative A. Rockfill deformation in alternative A is approximately equal to linear deformation modulus about $85 \mathrm{MPa}$, in alternative $\mathrm{B}$ $170 \mathrm{MPa}$, in alternative $\mathrm{C}-340 \mathrm{MPa}$.

For making SSS calculations the use was made of the software developed by M.P. Sainov [11]. Calculations were conducted in 2D formulation. Finite elements of enhanced accuracy with square or cubic approximation were used for creation of finite-element models of the structure. 


\section{Results}

\subsection{Dam with a concrete core}

The dam with a concrete core was proposed by a group of authors headed by V.F. Korchevsky [2]. Vertical concrete core inside the dam was proposed to be arranged as a seepage-control element (Fig. 1). The core is of a complicated structure and consists of two main parts. The core lower part (54 m high) is more massive and is made of vibrated concrete. The core width at the foot is $58 \mathrm{~m}$. At the foot through-the-thickness it is cut by a horizontal perimeter joint. The upper part is less massive; its maximum thickness makes up about $24 \mathrm{~m}$. It is made of RCC and is separated from the lower part by a through joint. Height-wise the core upper part it was proposed to make several joints-cuts (from the upstream part). For protection against seepage through RCC at the upstream face it is envisaged to install an asphalt concrete face. Transition zones are arranged at the contact between the core structure and the shells.

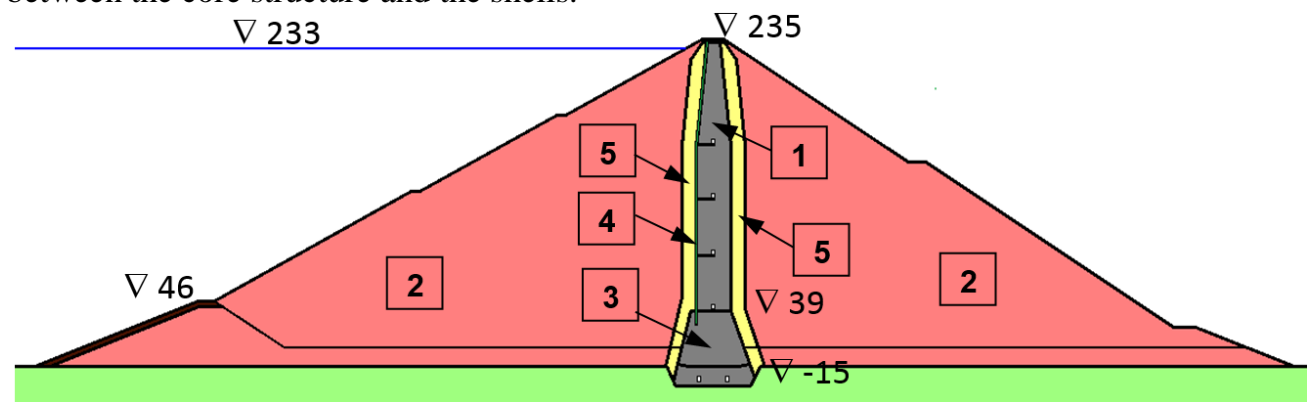

Fig. 1. Design of rockfill dam with a concrete core as a seepage control element

1- Concrete core of RCC, 2 - Rockfill shells, 3 - The base of the concrete core of vibrated concrete, 4 - Asphalt concrete face, 5 - Transition zones

The results of conducted SSS analyses are given in [12]. At SSS analyses the core material was adopted to be an elastic material; its deformability was described by modulus of linear deformation E and Poisson's number $v$. For the core lower part concrete the following parameters were adopted: $\mathrm{E}=29000 \mathrm{MPa}, v=0.18$, for the core upper part $\mathrm{RCC}$ $\mathrm{E}=20000 \mathrm{MPa}, v=0.20$, for asphalt concrete $\mathrm{E}=25 \mathrm{MPa}, v=0.40$.

SSS analyses showed that hydrostatic pressure is perceived mainly by a concrete core, the shells perceive only a small part of load. The core operational scheme is similar to the same of a cantilever embedded in the rigid foundation. Due to great displacements the perimeter joint (between the core and the foundation) opens for a large length. However, considerable joint openings do not compensate the concrete core bending deformations. The strongest bending deformations are typical for the core lower part toward the downstream side. Bend results in appearance of tensile stresses on the core upstream face and in concentration of compressive stresses on the downstream face. The core upper part is subject to bend toward the upstream side, therefore, tensile stresses are formed on the core downstream face, and compressive stresses are concentrated on the upstream face.

Analyses showed that in all the alternatives the tensile stresses in a concrete core exceed the design concrete tensile strength; therefore, formation of cracks in it should be expected. In the core lower part the failure of compressive strength may be expected. Even at high degree of rockfill compaction the cracking resistance is not provided both of the concrete core body and at the contact of its separate elements with the foundation. Thus, the considered dam structural design is not safe and workable. 


\subsection{Dam with a grout curtain}

In [13] we studied workability of a rockfill dam with massive grout curtain (Fig. 2). The grout curtain thickness was adopted to be variable by height. It was assumed that the same as the dam the grout curtain is constructed in three stages (lifts): injection is fulfilled for the whole height of the construction stage in parallel to filling soil of the next dam construction stage. The height of stages comprised 80, 161 and $235 \mathrm{~m}$ respectively. The curtain thickness was assigned to be equal about $20 \%$ of the head. For the first-stage dam the curtain thickness was adopted equal to $48 \mathrm{~m}$, for the second $31 \mathrm{~m}$, for the third $14 \mathrm{~m}$.

By the results of analyses the work conditions of each lift of the grout curtain differ. The upper lift, which is the last to be constructed, does not subject to any loads from the dam dead weight and mainly works in bending from hydrostatic pressure. The lower and the middle lifts work not only in bending, but take longitudinal compressive force, which is created from the dam dead weight and is transferred to the curtain through friction.

We showed that apart from the rockfill deformation the quality of the curtain SSS does not change [13]. The seepage-control element SSS is characterized by two main negative manifestations. The first is high probability of tensile strength failure and opening of the contact between the injection

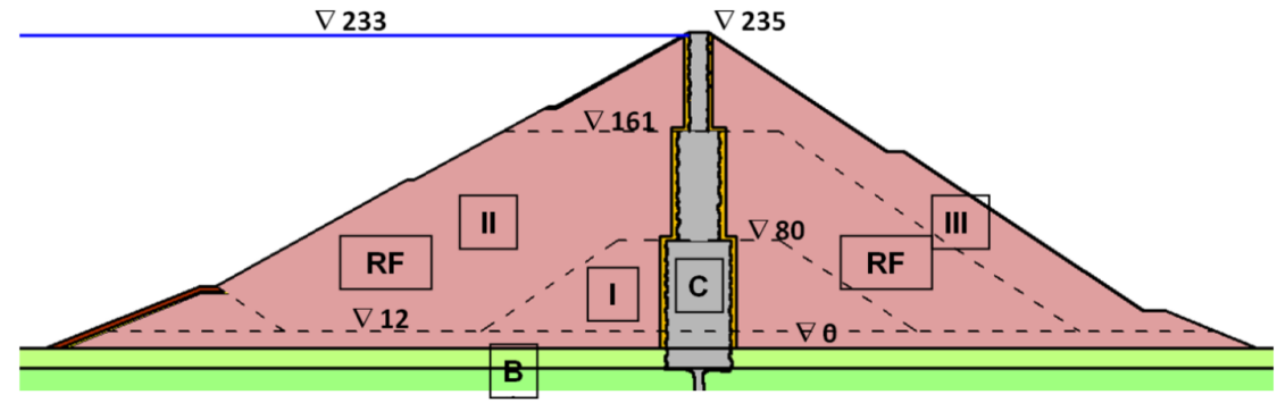

Fig. 2. Design of rockfill dam with an anti-seepage element as grout certain

C- grout certain, RF- Rockfill shells, B-bedrock base, I, II, III-construction project phases

diaphragm and rock foundation. The second is development of tensile stresses zone on the lower lift upstream face.

It was established that SSS of the grout curtain will be favorable only at proper selection of grout for creation of the grout curtain and proper compaction of rockfill. Rockfill in 200 $\mathrm{m}$ high dam should be compacted in the way to achieve the value of deformation modulus at least $300 \mathrm{MPa}$.

Deformation of the curtain material has even stronger impact on the dam workability. The more rigid is the material the higher is probability of tensile strength failure and opening of the contact joint. If the curtain material deformation modulus amounts to about $200 \mathrm{MPa}$ and less, the zones of tensile stresses will local by dimensions. It was established that curtain material deformation modulus should not exceed the deformation modulus of the dam body soil by more than $3 \div 5$ times. It is recommended for injection to use claycement grout but not cement grout.

Thus, massive grout curtains at meeting certain conditions may be used as seepagecontrol element of a high dam. However, it should be born in mind that rockfill SSS in such a dam may be unfavorable and may be characterized by development of soil limit state zones.

\subsection{Dam with a massive non-soil face}

Prof. L.N. Rasskazov proposed to use dams with massive face [8]. His proposal envisages in the concrete face rockfill dam (CFRD) arrangement of the under-face zone, not of soil 
but of soil-cement concrete. Soil-cement concrete is stone strengthened by poured cement grout and vibrated by vibrorollers. The first use of soil-cement concrete was in 1996 at Bovilla dam in Albania for arrangement of the seepage-control face [7].

In the considered ultra-high dam we chose a wide soil-cement concrete under-face zone: its thickness at the top was adopted equal $4 \mathrm{~m}$, in the lower part $14 \mathrm{~m}$ (Fig. 3). Jointly with placed reinforced concrete face on the top the under-face zone forms a massive non-soil face. The idea was that soil-cement concrete zone could enhance safety of the seepagecontrol face and provide its maintainability as well as improve the dam water tightness. During analyses the deformation modulus of soil-cement concrete was taken equal $5000 \mathrm{MPa}$.

SSS analyses [14] showed that the massive face resting on rock foundation operates as a rigid cantilever. Its upper part freely follows rockfill displacements and the lower part thrusts against rock and is not free in displacements. The face lower part is subject to bending deformations of a complicated character. Due to bending the contact of the face with rock opens, and the face upper surface is subject to tension. The value of tensile stresses in the reinforced concrete face considerably exceeds the concrete tensile strength. Tensile stresses also appear in the under-face zone made of soil-cement concrete. Appearance of transversal joints in the massive face should be expected.

Thus, replacement of a thin-walled reinforced concrete face with a massive double-layer face did not enhance safety of the dam seepage-control operation.

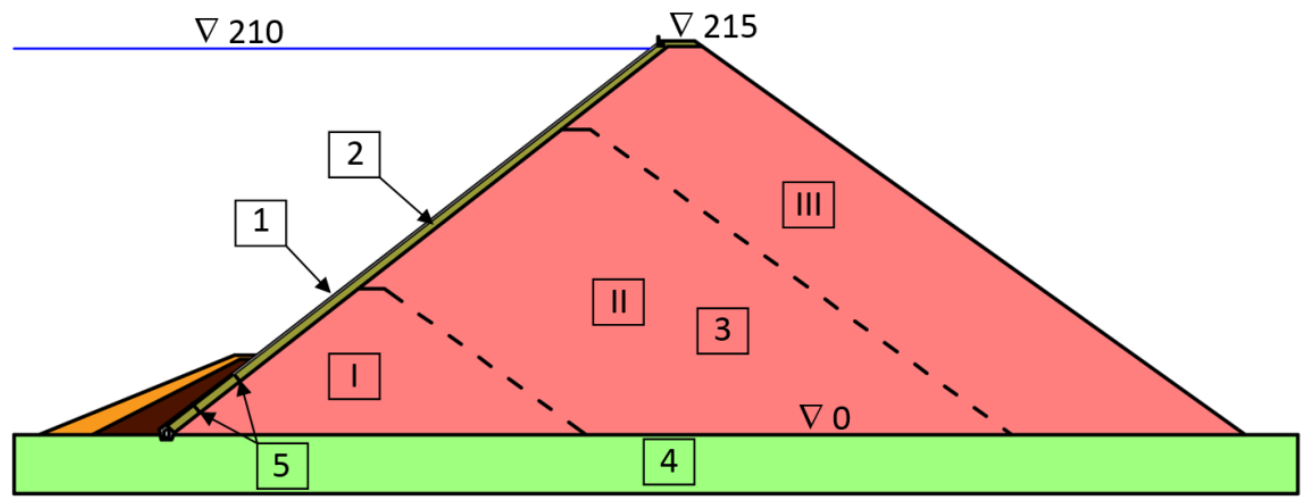

Fig. 3. Design of rockfill dam with a double-layer face made of reinforced concrete and soil-cement concrete. 1 - Reinforced concrete face, 2 - Under-face zone, 3 - Rockfill, 4 - Bedrock base,

5-Horizontal joint, I, II, III-construction project phases

\subsection{Dam with combination of a reinforced concrete face and grout curtain}

VNIIG engineers proposed to use the dam with combination of a reinforced concrete face and a grout curtain [1]. The idea of this structural design is in enhancing the dam maintainability due to possibility of packing grouts injection in the lower part of the seepage-control element.

Our investigations [15] showed that the proposed structural design (Fig.4) is a good alternative to classic structural design of a rockfill dam with a reinforced concrete face. In the considered dam design the reinforced concrete face operates in more favorable conditions: it is subject to not tensile, but to compressive longitudinal force. There appears a danger of not tensile, but compressive strength failure. To provide compressive strength of reinforced concrete face it is necessary to decrease deformation of rockfill (rockfill deformation modulus should be approximately at least $150 \mathrm{MPa}$ ) or increase its thickness. It is recommended to adopt the face thickness along the bottom equaling at least $2 \mathrm{~m}$. 


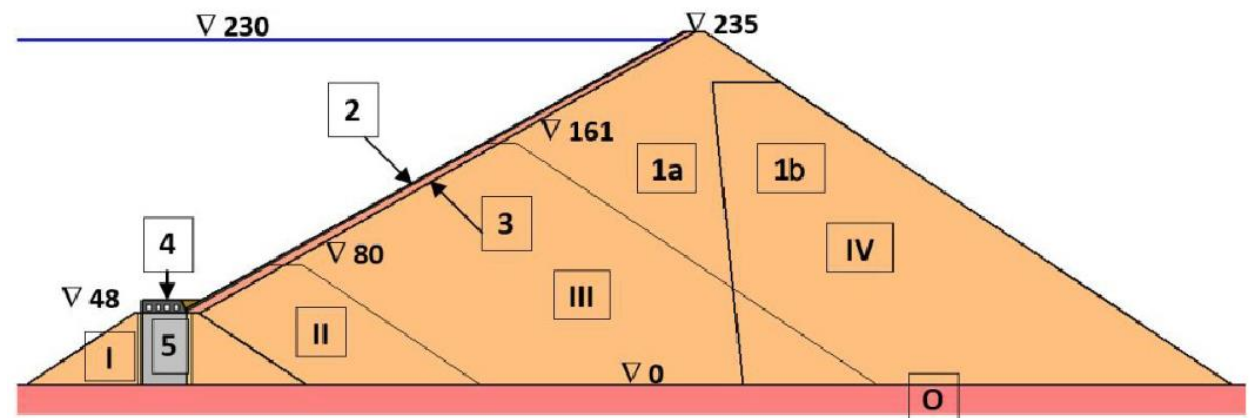

Fig. 4. Dam design with combination of seepage-control elements: a reinforced concrete face and a grout curtain. 1a, 1b - rockfill, 2 - Reinforced concrete face, 3 - Under-face zone, 4 - gallery, 5-grout curtain, I, II, III, IV -construction project phases

It was established that SSS of the reinforced concrete face lower part depends on the grout curtain material deformation modulus. To prevent considerable bending deformations of the reinforced concrete face, the grout curtain material deformation modulus should be not lower than that of rockfill.

Besides, the vulnerable zone of the combined seepage-control element is the contact of the grout curtain with rock foundation. To prevent cracking in the grout curtain body and at the contact "grout curtain-rock" it is necessary to obtain deformation modulus of the grouted soil to be not more than $500 \mathrm{MPa}$. It is recommended for grouting to use bentonitecement grouts.

\subsection{Dam with combination of a reinforced concrete face and a clay-cement concrete diaphragm}

In paper [9] there was proposed an alternative of the embankment dam structural design, where the reinforced concrete face is combined with not massive but thin-walled seepagecontrol element, i.e. with a diaphragm. This diaphragm may be constructed by bore piling method, which will permit speeding up construction rates. Based on recommendations [16], this diaphragm was proposed to be made of clay-cement concrete.

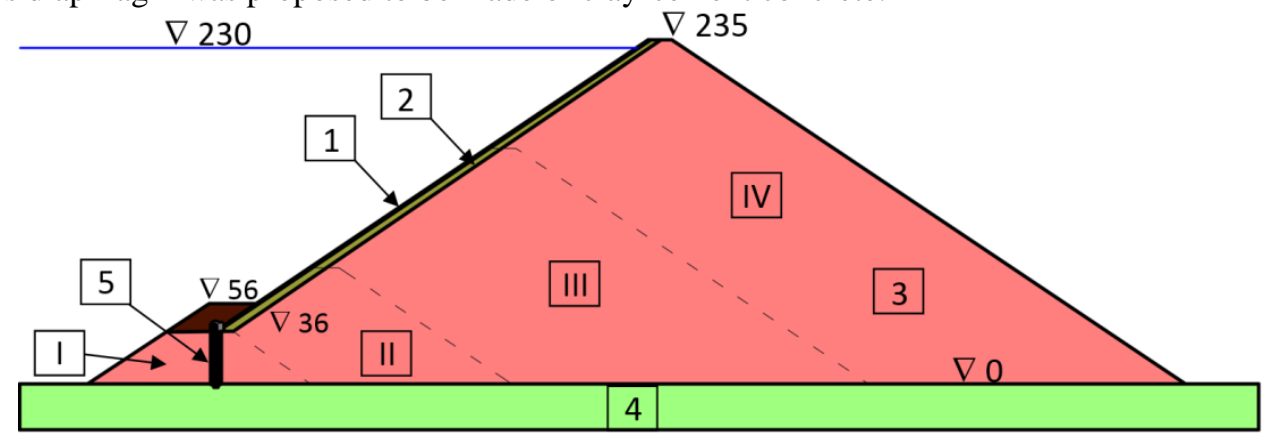

Fig. 5. Dam design with combination of a reinforced concrete face and a clay-cement concrete diaphragm. 1 - Reinforced concrete face, 2 - Under-face zone, 3 - Rockfill, 4 - Bedrock base, 5 - Diaphragm, I, II, III, IV -construction project phases

Studies of this structural (Fig.5) design were carried out by M.P. Sainov and V.B. Soroka $[9,17]$. The studies revealed that in the considered structural design the reinforced concrete face and the clay-cement concrete diaphragm operate in sufficiently favorable conditions. The reinforced concrete face is subject to longitudinal compressive force, but compressive forces perceiving by the clay-cement concrete diaphragm do not reach limit 
values. The proposed dam structural design may be sufficiently safe at meeting a number of conditions:

- rockfill deformation modulus should be at least $250 \mathrm{MPa}$;

- clay-cement concrete deformation modulus should be not more than 2 times as much as the rockfill deformation modulus;

- conjugation of the diaphragm with rock foundation is feasible to be fulfilled by arranging a clay-cement concrete «slab».

\section{Conclusions}

1. The main principle for selecting the material of the seepage-control element operating inside the soil mass is its degree of approximation by deformation to soil. Rigid structures are not acceptable for arranging seepage-control elements located inside the dam body.

2. In ultra-high rockfill dams it is preferable to use seepage-control element located not inside the dam, but on the surface of the upstream slope. This permits providing more favorable stress state of soil in the dam body, preventing development of limit state zones.

3. The perspective way of creating non-soil seepage-control elements of ultra-high dams is a combination of a reinforced concrete face with vertical structures made of clay and cement mix (diaphragms or curtains).

\section{References}

1. Zairova V.A., Filippova E.A., Orishhuk R.N., Sozinov A.D., Radchenko S.V. Vybor protivofil'tracionnogo ustrojstva v variantah plotin Kankunskogo gidrouzla [Selecting of anti-seepage elements Cancun dam variants] // Gidrotehnicheskoe stroitel'stvo [Hydraulic Engineering]. 2010. No.2. Pp.2-7. (In Russian)

2. Korchevskij F.V., Malyshev A.M., Kolichko A.V., Orehov V.V. Kankunskaja GJeS na r.Timpton v Respublike Saha (Jakutija): variant gruntovoj plotiny s jadrom iz ukatannogo betona [Cancun HPP on Timpton River in the Republic of Sakha (Yakutia): the version of the embankment dam with a rolled compacted concrete] // Gidrotehnicheskoe stroitel'stvo [Hydraulic Engineering]. 2010. No.2. Pp.11-22. (In Russian)

3. Marques Filho, P., De Pinto, N.L.S. CFRD dam characteristics learned from experience. International Journal on Hydropower and Dams. 2005. No.12 (1). Pp.72-76.

4. Xavier, L.V., Albertoni, S.C., Pereira R.F., Antunes J. Campos Novos dam during second impounding. The International Journal on Hydropower \& Dams. 2008. No.15. Pp.53-58.

5. Volynchikov A.N., Burdyukov B.A., Gaziev EH.G. Povedenie kamennonabrosnoj plotin Boguchanskoj GEHS v period napolneniya vodohranilishcha [Behavior of the rockfill dam of the Boguchanskaya HPP during the filling of the reservoir ] // Gidrotehnicheskoe stroitel'stvo [Hydraulic Engineering]. 2013. №9. Pp.10-17. (In Russian)

6. Orehov V.V. Naprjazhjonno-deformirovannoe sostojanie sverhvysokoj gruntovoj plotiny s asfal'tobetonnoj diafragmoj [Stress strain state of ultra-high rockfill dam with asphalt core] // Gidrotehnicheskoe stroitel'stvo [Hydraulic Engineering]. 2015. No5. Pp.57-59. (In Russian)

7. Sembenelli, P., Sembenelli, G. and Scuero, A. Bovilla: A Product of Dam History. Geotechnical Fabrics Report // IFAI Publishers. 1998. Volume 16. No.6. Pp.30-36.

8. Rasskazov L.N., Sainov M.P. Numerical investigation of reliability of a high earthen 
dam with a reinforced-concrete shield and sub-shield zone formed from soil-cement concrete. Power Technology and Engineering. 2012. Volume 46. No.2. Pp.116-120.

9. Sainov, M.P. Analysis of normal operation of a rockfill dam with combination of seepage-control elements: Reinforced concrete face and clay-cement-concrete wall. Magazine of Civil Engineering. 2016. No.64(4). Pp.3-9.

10. Rasskazov L.N., Dzhkha Dzh. Deformiruemost' i prochnost' grunta pri raschete vysokikh gruntovykh plotin [Deformability and Strength of Soils in High Soil Dam Calculation]. Gidrotekhnicheskoe stroitel'stvo [Hydraulic Engineering]. 1987. No.7. pp. 31-36. (In Russian)

11. Sainov M.P. Vychislitelnaya programma po raschyotu napryazhyonnodeformirovannogo sostoyaniya gruntovykh plotin: opyt sozdaniya, metodiki i algoritmy [Computer program for the calculation of the stress-strain state of soil dams: the experience of creation, techniques and algorithms] // International Journal for Computational Civil and Structural Engineering. 2013. Vol.9. No.4. Pp.208-225. (In Russian)

12. Kotov F.V. Rabotosposobnost' sverhvysokoj kamenno- nabrosnoj plotiny s protivofil'tracionnym ehlementom $\mathrm{v}$ vide betonnogo yadra [Reliability of ultra-high rockfill dam with concrete core] // Internet-zhurnal Naukovedenie [Internet Journal of Science] 2017. Vol.9. №6. URL: https://naukovedenie.ru/PDF/83TVN617.pdf (In Russian)

13. Sainov, M.P., Kotov, F.V. Stress-strain state and performance of a high rockfill dam with a grout curtain // Magazine of Civil Engineering. 2017. No.1(69). Pp.44-55.

14. Sainov M.P., Kotov F.V. Napryazhenno-deformirovannoe sostoyanie dvuhslojnogo ehkrana kamennonabrosnoj plotiny, vypolnennogo iz zhelezobetona i gruntocementobetona [Stress-strain state of rockfill dam double-layer face made of reinforced concrete and soil-cement concrete] // Vestnik MGSU [Proceedings of Moscow State University of Civil Engineering]. 2017. Vol.12. №5(104). Pp.506-511.

15. Sainov, M.P., Kotov, F.V., Nazarov, N.V. Serviceability of rockfill dam with reinforced concrete face and grout curtain. Magazine of Civil Engineering. 2018. No.79(3). Pp.77-85.

16. Sainov, M.P., Lubyanov, V.V. Stress-strain state of seepage-control walls in foundations of embankment dams. Magazine of Civil Engineering. 2017. No.5(73). Pp.96-112.

17. Sainov M.P., Soroka V.B. Rabotosposobnost' sverhvysokoj kamenno-nabrosnoj plotiny $\mathrm{s}$ kombinaciej negruntovyh protivofil'tracionnyh ustrojstv [Workability of a ultra-high rockfill dam in combination with non-soil seepage-control facilities] // Privolzhskij nauchnyj zhurnal [Privolzhsky scientific journal]. 2017. №3(43). Pp.70-76. 